\title{
Born Global in Bangalore: Emergent Pathways for International New Ventures via Multinational Enterprise Networks
}

\author{
Shameen Prashantham, Nottingham University Business School, China
}

IN THIS PAPER I DISCUSS UNDER-RESEARCHED possibilities at the interface of international new ventures (INVs) and multinational enterprise (MNE) networks. Writing on the occasion of the $25^{\text {th }}$ anniversary of the Journal of International Business Studies (JIBS), Wright and Ricks (1994) predicted that an important future research direction in international business (IB) would concern the internationalization of entrepreneurial ventures. Their prediction has come true. That very year, Oviatt and McDougall (1994) published their seminal piece on INVs, whose influence was recognized with the JIBS Decade Award in 2004. Speaking on the occasion, Zahra (2005) noted that these scholars had created a welcome shift in the international business research conversation away from an exclusive focus on the large established MNE to include the INV ${ }^{1}$ as a legitimate player on the global stage. While tremendous progress has been made in INV research, the argument made here is that it is perhaps time for a further shift in the conversation - such that INVs or born globals are viewed not merely as being distinct from large MNEs (which of course they are) but also as actors on the global stage who interface with large MNEs in myriad ways.

The possibilities at the MNE-INV interface, which was the focus of a panel discussion ${ }^{2}$ at the 2012 AlB conference in Washington DC, represent a potentially major research opportunity in IB research for scholars with an interest in new venture internationalization and MNE networks. Recent thinking on MNE networks suggests that opportunities arise for internationally-minded, innovative new ventures to leverage the innovation ecosystems of MNE's networks (Buckley, 2009). This mirrors a major change in the thinking of CEOs of large MNEs away from an insular focus on the MNE to a wider focus on the interorganizational networks that they seek to orchestrate (Dhanaraj \& Parkhe, 2006). Nokia's CEO Stephen Elop has described the global competitive landscape as "a war of ecosystems." Thus new ventures do not operate in an environment

1 Some scholars use the term born global (Knight \& Cavusgil, 2004). Alan Rugman and colleagues correctly point out that many INVs are more likely to be born regionals; thus born globals are likely to be a subset of the INV population. For ease of exposition, the terms INV and born global are used changeably here.

2 AIB members can view the video for this panel at https://aib.msu. edu/login/?redirect=/events/2012/Videos/ShowPlenaryVideo. asp? videoid=32.

3 See http://www.nokia.com/global/about-nokia/about-us/the-nokia-story/ that is disembodied from large MNE networks. But 'twas not ever thus. Changes have occurred over time, both on the part of MNEs in terms of their motivation and capacity to engage with INVs, and in the desire and ability of new ventures to partner with MNEs. The underlying factor in both of these is upward shifts in innovation, both in technology and management practices at the MNE-INV partner interface.

An emerging economy setting such as Bangalore offers a vantage point for gaining an especially vivid view of such shifts, and the unfolding of MNE-INV engagement, due to its growing sophistication over time. In my research on the internationalization of new ventures in the Bangalore software industry, spanning three phases over a decade, I have become aware of an upward trajectory in, and interface between, innovative activities of both foreign MNEs and indigenous new ventures. My research began early in the twenty-first century, when the phenomenon of "Bangalorization" - the migration (and loss) of jobs through outsourcing and offshoring - led to a corresponding emergence of born globals in places like Bangalore i.e. new ventures that internationalized almost from inception, as recipients of offshored business opportunities. As I expand below, studying INVs in Bangalore over time, from that staring point, has proved useful in yield a more complete picture of the complexity and dynamics of the MNE-INV partner interface.

\section{The flipside of "Bangalorization"}

My first phase of research (2002-5) in the Bangalore software industry took place in a context of opportunity for new venture internationalization stemming from the reputation effects associated with successful $\mathrm{Y} 2 \mathrm{~K}^{4}$ software development projects. This was also a period of post-dot com crash aftershock which had curtailed some IT spending. Arguably the need for cost-cutting among Western firms was an opportunity as well, but smaller entrepreneurial firms were finding it harder to grow vis-à-vis their established large competitors like Infosys. Given the lack of a recognizable brand name, new ventures in Bangalore resorted to actively cultivating overseas network relationships. Those ventures founded by "returnees" — Indians returning home after a spell abroad

4 The so-called Y2K problem resulted from the conventional use of two digits to represent a four-digit year in digital data during the 20th century. 
- were typically advantaged, since they had overseas ties that they could tap into. While the leveraging of network ties is not uncommon for new ventures, a distinctive facet of many of these relationships was coethnicity. That is, Bangalore-based software entrepreneurs tended to look to overseas actors of Indian origin, some of them linked through kinship, to assist with their ventures' internationalization.

Such a networking strategy did have certain benefits. Survey data on Indian software ventures indicates that ethnic ties did indeed result in a deeper presence in host markets through higher-commitment entry modes (Prashantham, 2011). But longitudinal case-studies in Bangalore suggest that over time it is important to broaden the portfolio of ties to learning outcomes from relationships over time even if (direct) revenue-generating opportunities recede (Prashantham \& Dhanaraj, 2010).

\section{Upping the ante, dancing with gorillas}

As the first decade of the twenty-first century wore on, it became apparent to many Indian IT firms that competition - from other Indian companies, MNE operations in India, and other emerging economies - was becoming fiercer. The pressure was acutely felt by smaller entrepreneurial firms. This necessitated a response. In the case of Ekomate the response was market diversification. Thus they actively looked to non-English speaking markets, such as Italy, where the Indian diaspora did not have quite the presence as it does in markets like the US or UK. This required Ekomate to step outside of its comfort zone to cultivate non-ethnic ties and adapt its routines and processes to this market.

A different, albeit relatively rare, response was to up the ante through product diversification, in particular renewing the firm's capability set to operate as a software product company

include non-ethnic ties (Prashantham \& Dhanaraj, 2010). Consider for example the case of Ekomate, an entrepreneurial software venture in Bangalore which successfully internationalized into markets such as the US and UK, primarily by leveraging overseas ethnic ties. As competition in these markets increased, Ekomate diversified its portfolio of markets to include New Zealand and Italy by expanding its networks to include non-ethnic ties, and seeking to learn from initial and subsequent ties to augment its technology and business capability set.

Thus Ekomate represents the case of an INV in Bangalore that:

- took advantage of Bangalore's growing reputation for software services development;

- cultivated overseas ties, several with coethnics but eventually with non-ethnics, although engagement with MNEs was minimal;

- successfully internationalized on the basis of providing competent software services at competitive prices.

Ekomate's experiences suggest three important lessons. First, internationalization activity requires the active leveraging of network ties, often based on bonds of common cultural identity. For INVs, entrepreneurs' overseas ethnic ties, if cultivated and utilized, can help them cope with challenging high-psychic distance markets (Prashantham \& Floyd, 2012). Second, successful internationalizing calls for discerning leverage of network ties, in particular by recognizing that different types of relationships are useful for different things, and that the ties that help young internationalizing Indian software firms initially may not be the ones that help later on (Prashantham \& Young, 2011). Third, with the passage of time, sustained internationalization entails the reflective leveraging of network ties i.e. the conscious focus on extracting (indirect) rather than a software services company. Developing and selling software products is an altogether more daunting proposition calling for radical, rather than incremental, innovation and involving higher levels of uncertainty. Such a transformation is exemplified by another Bangalore-based firm, Skelta, which had originally been a software services start-up. But by the time I began my second phase of research (2005-8), Skelta had signalled its intent to be a software product company targeting Western markets. In a country with few examples of internationally successful product companies, this was a bold step. An early strategic decision was to build the product on Microsoft platform technology - meaning, in effect, that its offering would be a complement to that MNE's innovation ecosystem. Unsurprisingly, the CEO and his top management team sought to forge a strong relationship with Microsoft, an approach that can be fraught with risk for new ventures, as alluded to by the description of such partnerships as "dancing with gorillas" (Prashantham \& Birkinshaw, 2008).

Being based in Bangalore proved to be a mixed blessing. In those days, Microsoft's engagement with smaller independent software vendors (ISVs) like Skelta was at a nascent stage, especially so in its emerging economy operations. Thus Skelta had to blaze a trail to make the relationship a reality. On a positive note, though, the subsidiary was entrepreneurial and receptive to the proactive overtures of this young company - and there weren't too many companies like it at the time. In addition to thereby gaining the subsidiary's attention, Skelta was also able to leverage the high priority that Microsoft's headquarters accorded India as evidenced by regular visits from high-ranking executives. Skelta was often "showcased" to such individuals and through links made with them, many of whom were of Indian origin, Skelta was able to extend the reach of its relationship with that MNE beyond the 
confines of India. Over time, Skelta's persistent relationship-building with Microsoft entities in India and overseas led to it being assigned a partner manager not only within Microsoft India but also in the US. Furthermore, Skelta coopted Microsoft partners from over 20 countries across all of the major regions, to act as its own re-seller ecosystem. Both of these outcomes had a direct and powerful influence on its rapid internationalization.

Thus Skelta represents the case of an INV in Bangalore that:

- responded to changing environmental pressures (and opportunities) to transform its product-market mix and capability set from that of a software services to a software product firm;

- engaged in boundary-spanning within and across national frontiers to develop a portfolio of network ties largely centred around Microsoft's wider ecosystem (or global factory);

- successfully internationalized on the basis of an innovative offering that was a complement to an MNE's ecosystem.

\section{Advancing from the periphery to the core of MNE networks}

During the third phase of my research (2008-11), I began to find that with improvements to the entrepreneurial ecosystem in Bangalore and entrepreneurs' rising aspirations, a small but discernible minority of new ventures that were IP-centric from inception had emerged. These new ventures increase the odds of swiftly shifting their engagement from the periphery (subsidiary-level) to the core (headquarters) of MNE networks by focusing on innovation from inception in a way that leveraged unique locationally-embedded advantages. In emerging economies like India and China, frugal innovation, targeting bottom-of-the-pyramid (BOP) markets (Prahalad, 2004), represents one firm of locationallyembedded advantage.

A case in point is Mango, a start-up that, from inception, focused on building a software product with a niche focus on mobile telephony for BOP segments. Mango's CEO viewed partnering with an MNE as the way forward for the venture to scale up its technology and take it to market, not just in India but also other developing countries with lowincome segments. Mango was incubated within the prestigious Indian Institute of Management Bangalore. During this time it forged an effective relationship with the American MNE, Qualcomm. Having explored multiple MNE ties (in parallel), Mango succeeded in showcasing its technology to a visiting Qualcomm manager at a partner-networking event. The technology got the manager's immediate attention because it became rapidly evident to him that Mango's technology could fill a gap in Qualcomm's own offering. This encounter set off a string of incremental steps which resulted in Mango's rapid internationalization by leveraging the MNE as a conduit to large BOP markets, e.g., China and
Indonesia, and later reached a lucrative culmination in a sale of intellectual property (IP) by Mango to Qualcomm.

This illustration exemplifies the emergent opportunities in economies like India whereby innovative new ventures could help MNEs fill-in-theblanks of their product portfolios, and in so completing their offering shift the locus of engagement decisively from the periphery to the core of MNE networks. This is consistent with Buckley's (2006: 687) observation that: "electronic communication has opened new areas for small firms to fill in completing the networks of the MNE... as part of a symbiotic network with large firms...Indeed, large firms are often the conduit for the diffusion of SME innovations".

Thus Mango represents a case of an INV in Bangalore that:

- was conceived and founded as an IP-centric new venture focused on frugal innovation, and leveraged the growing sophistication of Bangalore's entrepreneurial ecosystem;

- engaged in boundary-spanning within Qualcomm, rapidly converting its local relationship at the periphery of the MNE network to a global relationship centered at the core;

- successfully internationalized by leveraging the MNE as a conduit to international markets through completing the offering of an MNE through locationally-embedded advantages.

Of course this is still a rare phenomenon in reality but what the Mango case shows is that it is possible - and perceptions of what is possible (even if not highly probable) could affect future behaviors of born globals in places like Bangalore in the pursuit of (rare) success such as Mango's; successes like this drive up the aspirations of peers. The odds of repeating these successes will likely increase, especially as connectedness between the India subsidiary and global headquarters of MNEs increases, and as Bangalore strengthens its entrepreneurial ecosystem in a bid to outgrow its "junior partner" status (Lorenzen \& Mudambi, 2013), and stakes its claim as a world-class technology cluster in its own right.

\section{Beyond Bangalore: energizing a wider research agenda}

As the next step in this research program, I am exploring the emergent MNE-INV interface in Beijing's Zhongcuancun district. Clearly, here too new ventures have the potential to leverage locationally-embedded points of advantage to partner with MNEs. But a major contrast I have noted with the Bangalore-based new ventures I studied is their pri- 
marily domestic market orientation. A fascinating question that arises is: Under what conditions do local relationships transform into global ones? Much theorizing remains to be done on, for instance, the role of entrepreneurial boundary-spanning from the perspective of both MNEs and new ventures. ${ }^{5}$ And in so doing, the more remarkable we are likely to find the phenomenon of the born global in Bangalore.

\section{References}

Buckley, P. J. 2006. International expansion: Foreign direct investment by small- and medium-sized enterprises. In M. Casson, B. Yeung, A. Basu \& N. Wadeson (Eds.), Oxford Handbook of Entrepreneurship: 671-692. New York: Oxford University Press.

Buckley, P. J. 2009. Internalisation thinking: From multinational enterprise to global factory, International Business Review, 18: 224-235.

Dhanaraj, C., \& Parkhe, A. 2006. Orchestrating innovation networks. Academy of Management Review, 31(3): 659-669.

Knight, G. A., \& Cavusgil, S. T. 2004. Innovation, organizational capabilities, and the born-global firm. Journal of International Business Studies, 35: 124-141.

Lorenzen, M., \& Mudambi, R. 2013. Clusters, connectivity and catch-up: Bollywood and Bangalore in the global economy. Journal of Economic Geography, 13(3): 501-534.

Prashantham, S. 2011. Social capital and Indian micromultinationals. British Journal of Management, 22(1): 4-20.

Prashantham, S., \& Birkinshaw, J. 2008. Dancing with gorillas: How small firms can effectively partner with multinational corporations. California Management Review, 51(1): 6-23.

Prashantham, S., \& Dhanaraj, C. 2010. The dynamic influence of social capital on the international growth of new ventures. Journal of Management Studies, 47: 967-994.

Prashantham, S., \& Floyd, S. W. 2012. Routine microprocesses and capability learning in international new ventures. Journal of International Business, 43: 544-562.

Prashantham, S., \& Young, S. 2011. Post-entry speed of international new ventures. Entrepreneurship Theory \& Practice, 35(2): 275-292.

Oviatt, B. M., \& McDougall, P. P. 1994.Toward a theory of international ventures. Journal of International Business Studies, 25: 45-64.

5 Having begun by making reference to Oviatt and McDougall (1994), it is perhaps fitting to note that one of these pioneering scholars, Prof. Tricia McDougall, was the Program Chair of the 2013 AIB Conference in Istanbul, Turkey. This unprecedented involvement of an entrepreneurship scholar in IB's scholarly community augurs well in that a deeper understanding of INV-MNE engagement will benefit from closer collaboration between IB and entrepreneurship researchers.
Wright, R. W., \& Ricks, D. A. 1994. Trends in international business research: Twenty-five years later. Journal of International Business Studies, 25: 687-701.

Zahra, S. A. 2005. A theory of international new ventures: A decade of research. Journal of International Business Studies, 36: 20-28.

Shameen Prashantham is an Associate Professor in International Business \& Strategy at Nottingham University Business School China. His research focuses primarily on international new ventures, in particular the influence of MNE networks on these firms' internationalization, and is published in California Management Review, International Business Review, Journal of International Business Studies and Journal of Management Studies, among other outlets, and in a monograph, The Internationalization of Small Firms: A Strategic Entrepreneurship Perspective (Routledge, London). 